Supporting Information

\title{
Biocatalytic Carbon-Hydrogen and Carbon-Fluorine Bond Cleavage through Hydroxylation Promoted by a Histidyl-Ligated Heme Enzyme
}

Yifan Wang ${ }^{\dagger}$, Ian Davis ${ }^{\dagger}$, Inchul Shin ${ }^{\dagger}$, Daniel J. Wherritt ${ }^{\dagger}$, Wendell P. Griffith ${ }^{\dagger}$, Kednerlin Dornevil ${ }^{\dagger}$, Keri L. Colabroy ${ }^{\ddagger}$, and Aimin Liu ${ }^{*}, \dagger$

†Department of Chemistry, University of Texas, San Antonio, Texas 78249, and

tDepartment of Chemistry, Muhlenberg College, Allentown, PA 18104, United States

*Correspondence to:

Aimin Liu, Department of Chemistry, University of Texas at San Antonio, 1 UTSA

Circle, San Antonio, TX 78249-0698; Phone: +1-210-458-7062; Fax: 210-458-7428;

and E-mail: Feradical@utsa.edu

\section{Table of Contents}

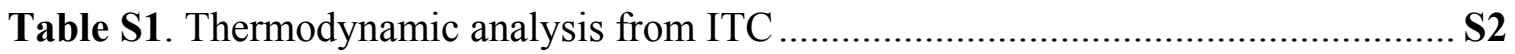

Table S2. Quantitative analysis on products of 3-halogen-L-tyrosines using HPLC ...... S3

Figure S1. LmbB2 reaction with L-phenylalanine and $O$-methyl-L-tyrosine .................S4

Figure S2. EPR spectra of ferrous enzyme-NO complex alone and with unbound phenols

Figure S3. ITC binding assays of LmbB2 with reactive tyrosine analogs.................... S6

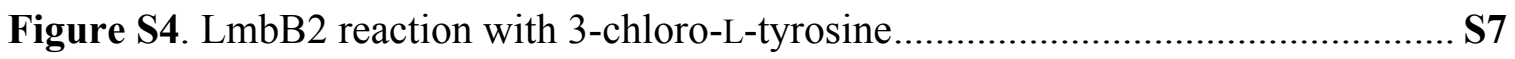

Figure S5. LmbB2 reaction with 3-iodo-L-tyrosine................................................ S8

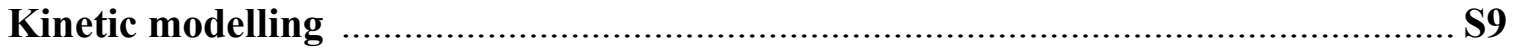

Scheme S1. Minimal competitive model for L-tyrosine ................................... S9

Figure S6. Catalase competition assays as fit by Scheme S1 .........................S10

Scheme S2. Minimal competitive model for 3-fluoro-L-tyrosine ....................S11

Figure S7. Catalase competition assays as fit by Scheme S2 ......................S12

Figure S8. MS analyses on unreacted substrates with ${ }^{18} \mathrm{O}$ labeled $\mathrm{H}_{2} \mathrm{O}$ or $\mathrm{H}_{2} \mathrm{O}_{2} \ldots \ldots \ldots$. S13

Figure S9. LmbB2 redox potential measurement .................................................. S14

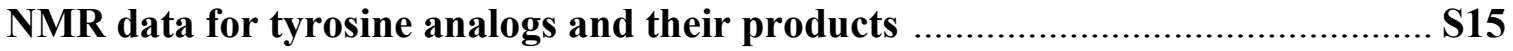


Table S1. Thermodynamic analysis of L-tyrosine (1), L-phenylalanine (2) and $O$-methylL-tyrosine (3), 3-fluoro-L-tyrosine (5), 3-chloro-L-tyrosine (6), 3-iodo-L-tyrosine (7) binding to LmbB2 as obtained from ITC. The fitting was done for one-site binding model. $N$ values for $\mathbf{2}$ and $\mathbf{3}$ were adopted from the results of $\mathbf{1}$.

\begin{tabular}{cccccc}
\hline Ligand & $\mathbf{N}$ & $\boldsymbol{K}_{\mathbf{A}} \times \mathbf{1 0}^{\mathbf{- 3}}\left(\mathbf{M}^{\mathbf{- 1}}\right)$ & $\boldsymbol{K}_{\mathbf{D}}(\boldsymbol{\mu M})$ & $\Delta \mathbf{H}(\mathbf{k c a l} / \mathbf{m o l})$ & $\Delta \mathbf{S}(\mathbf{c a l} / \mathbf{m o l} / \mathbf{d e g})$ \\
\hline $\mathbf{1}$ & $0.24 \pm 0.00$ & $739 \pm 18$ & $1.35 \pm 0.03$ & $-2032 \pm 80$ & -42.5 \\
$\mathbf{2}$ & 0.24 & $3.1 \pm 0.8$ & $318 \pm 8$ & $-7599 \pm 98$ & -9.9 \\
$\mathbf{3}$ & 0.24 & $0.77 \pm 0.01$ & $1292 \pm 22$ & $-1294 \pm 141.4$ & -30.9 \\
$\mathbf{5}$ & $0.24 \pm 0.01$ & $45.1 \pm 2.3$ & $22.2 \pm 1.1$ & $-1597 \pm 493$ & -33.2 \\
$\mathbf{6}$ & 0.24 & $2.9 \pm 0.2$ & $346 \pm 2$ & $-1916 \pm 698$ & -49.5 \\
$\mathbf{7}^{1}$ & 0.24 & $0.128 \pm 0.003$ & $7817 \pm 183$ & $-25650 \pm 5110$ & -865 \\
\hline
\end{tabular}

${ }^{1}$ Values are reported with uncertainty due to weak binding affinity close to the detection limit. 
Table S2. Quantitative analysis on products of 3-halogen-L-tyrosines using HPLC. Each substrate reacts with LmbB2 generating two products, i.e., DOPA and 3-halogen-5-hydroxyl-L-tyrosine (3-X-5-OH-Tyr).

\begin{tabular}{|c|c|c|c|c|c|c|c|}
\hline Substrate & $A_{\text {DOPA }}$ & A3-X-5-OH-Tyr & $\mathbf{A}_{\text {unreacted substrate }}$ & A total substrate & Conversion \% & $\begin{array}{c}\text { Normalized } \\
\text { A DOPA }\end{array}$ & $\begin{array}{c}\text { Relative } \\
\text { Ratio }\end{array}$ \\
\hline $\begin{array}{l}\text { 3-Fluoro-L- } \\
\text { tyrosine }\end{array}$ & $6.33 \pm 0.03$ & $9.83 \pm 0.04$ & $27.61 \pm 0.24$ & $44.89 \pm 0.79$ & $45.2 \pm 2.2$ & $14.02 \pm 0.70$ & 4.5 \\
\hline $\begin{array}{l}\text { 3-Chloro-L- } \\
\text { tyrosine }\end{array}$ & $2.78 \pm 0.15$ & $22.52 \pm 0.77$ & $13.94 \pm 0.65$ & $43.90 \pm 0.53$ & $68.2 \pm 3.3$ & $4.07 \pm 0.30$ & 1.3 \\
\hline $\begin{array}{l}\text { 3-Iodo-L- } \\
\text { tyrosine }\end{array}$ & $1.28 \pm 0.14$ & $12.79 \pm 0.75$ & $42.97 \pm 2.59$ & $73.15 \pm 2.56$ & $41.3 \pm 2.9$ & $3.10 \pm 0.39$ & 1 \\
\hline
\end{tabular}

Note: Conversion $\%=\mathrm{A}_{\text {unreacted substrate }} / \mathrm{A}_{\text {total substrate }}$ Normalized $A_{D O P A}=A_{D O P A} /$ conversion $\%$ 

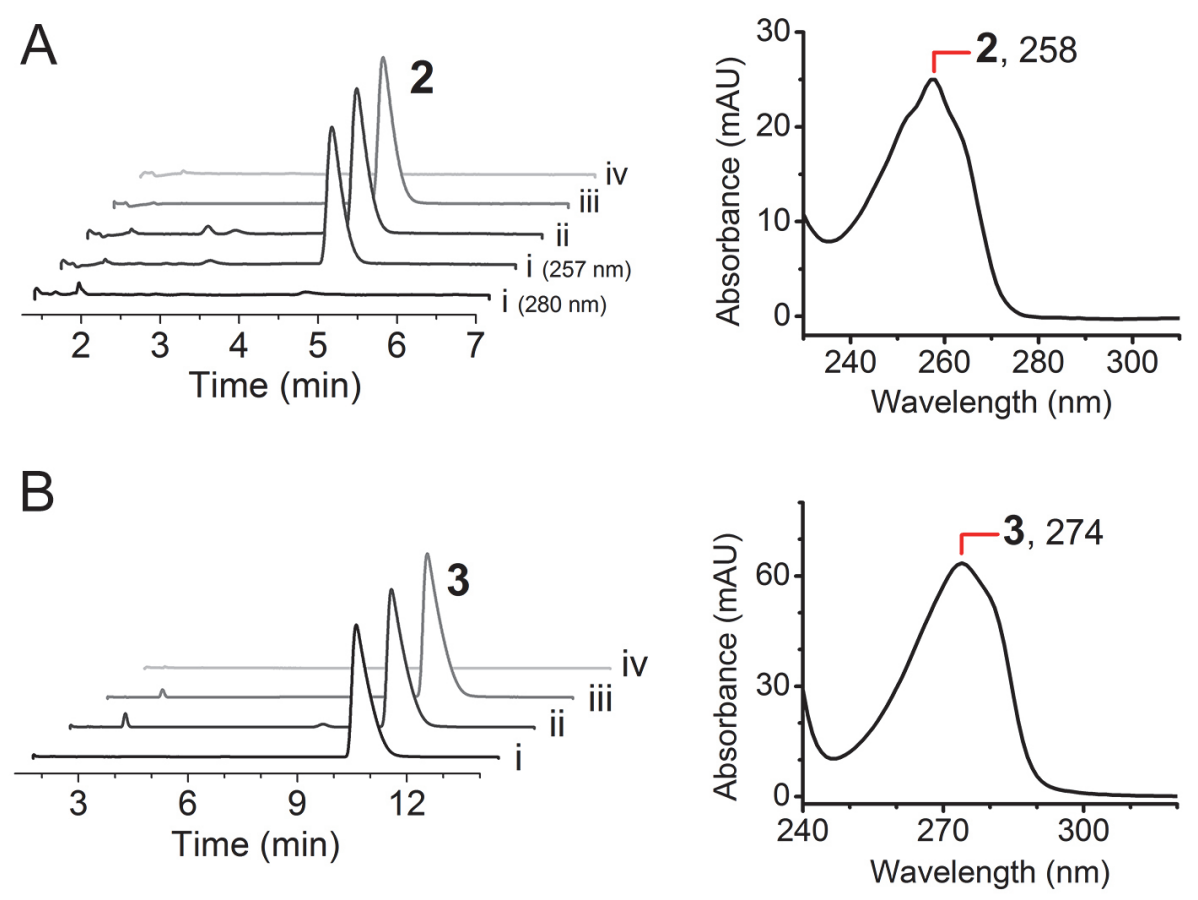

Figure S1. HPLC profile and peak absorbance of LmbB2 reaction with (A) Lphenylalanine (2) and (B) $O$-methyl-L-tyrosine (3) in the presence of hydrogen peroxide. The enzymatic reaction (i) consisted $100 \mu \mathrm{M}$ enzyme, $3 \mathrm{mM}$ substrate analog and $3 \mathrm{mM}$ $\mathrm{H}_{2} \mathrm{O}_{2} . \mathrm{H}_{2} \mathrm{O}_{2}$ was titrated to initiate the reaction by adding multiple times and small volume each time to final concentration of $3 \mathrm{mM}$ to avoid heme bleaching. Three controls consisted (ii) enzyme with substrate analog, (iii) substrate analogue with $\mathrm{H}_{2} \mathrm{O}_{2}$ and (iv) enzyme with $\mathrm{H}_{2} \mathrm{O}_{2}$. There was no reaction detected even when up to $20 \mathrm{mM}$ analog concentration was used with both $\mathrm{H}_{2} \mathrm{O}_{2}$ and PAA. Absorbance was monitored at both 257 and $280 \mathrm{~nm}$ for $\mathbf{2}$ and $280 \mathrm{~nm}$ for $\mathbf{3}$. 

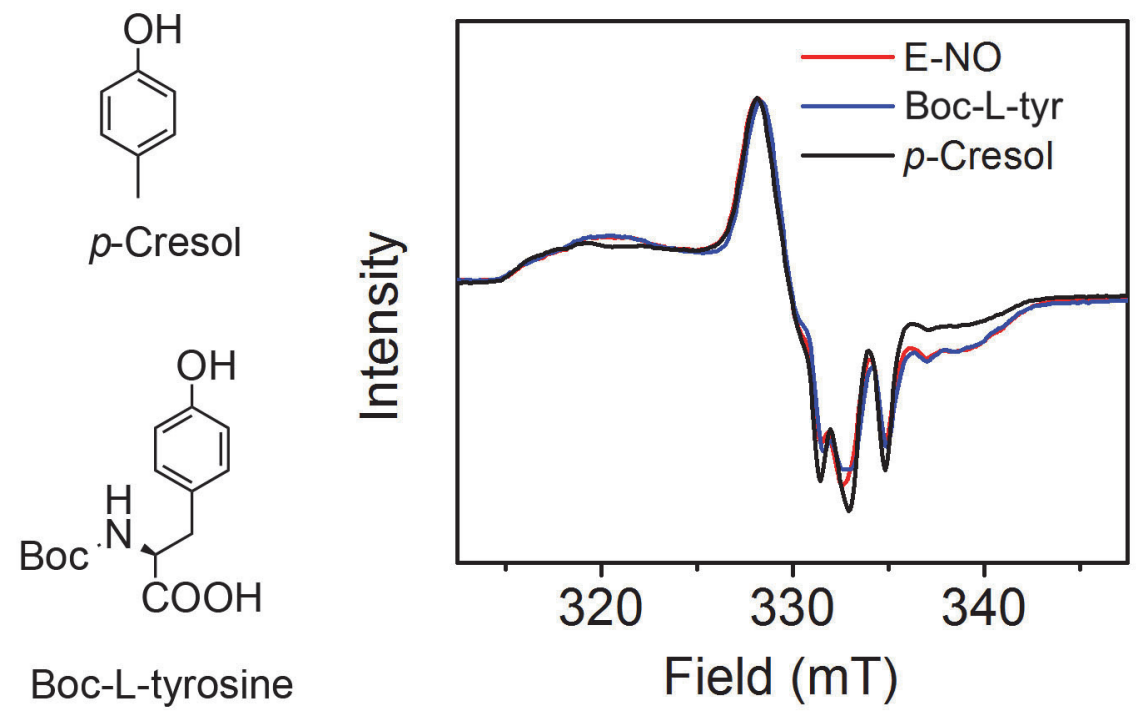

Figure S2. EPR spectra of ferrous enzyme-NO complex alone and with unbounded phenols, $N$-Boc-L-Tyrosine and $p$-Cresol. The overall EPR signals have no significant difference and $g_{\text {ave }}$ values are identical $\left(g_{\text {ave }}=2.030\right)$. All spectra were obtained at $50 \mathrm{~K}$, 9.4 GHz microwave frequency and $0.05 \mathrm{~mW}$ power. 

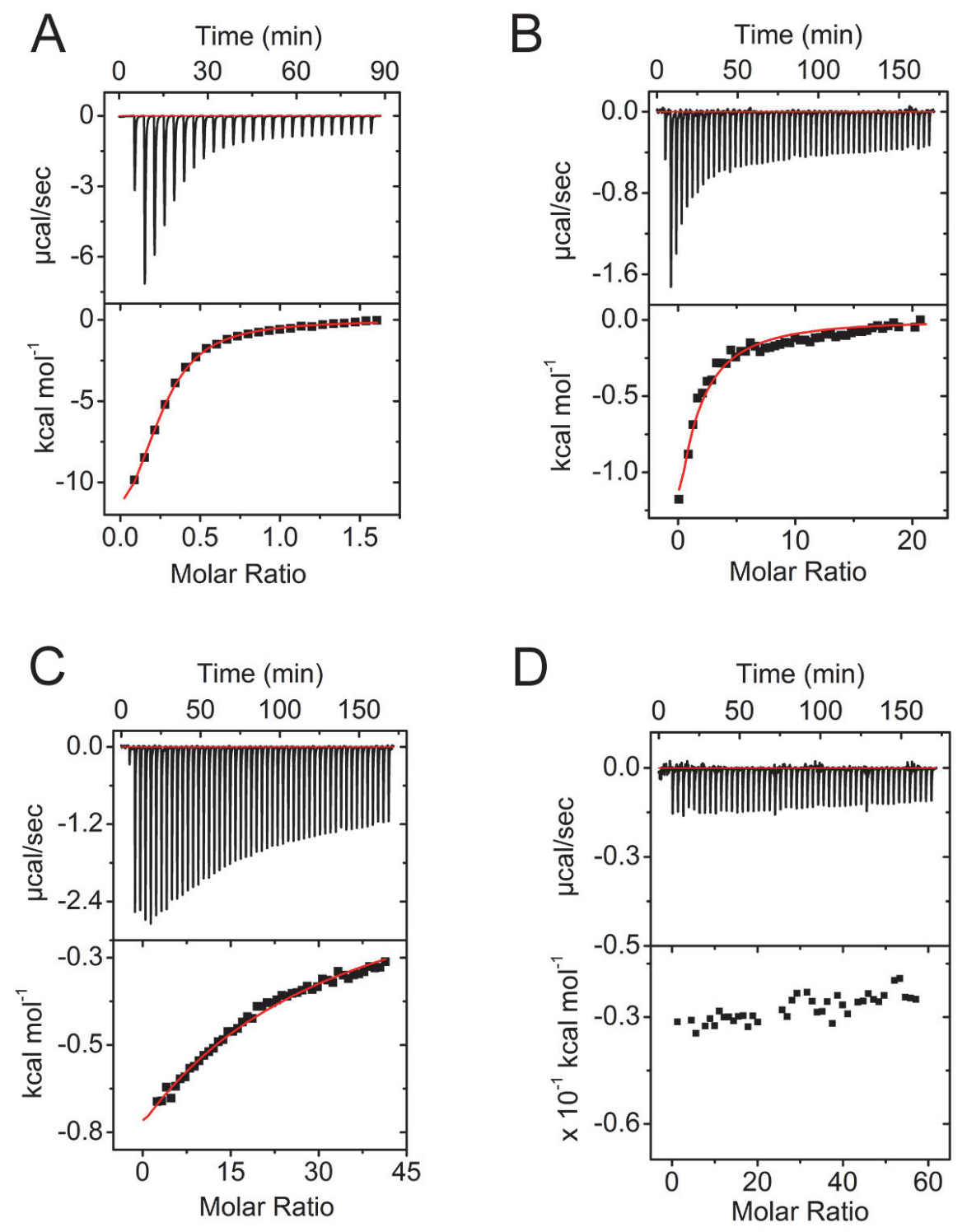

Figure S3. ITC binding assays of LmbB2 with reactive tyrosine analogs. (A) 3-fluoro-Ltyrosine; (B) 3-chloro-L-tyrosine; (C) 3-iodo-L-tyrosine; (D) 3-nitro-L-tyrosine. 
A
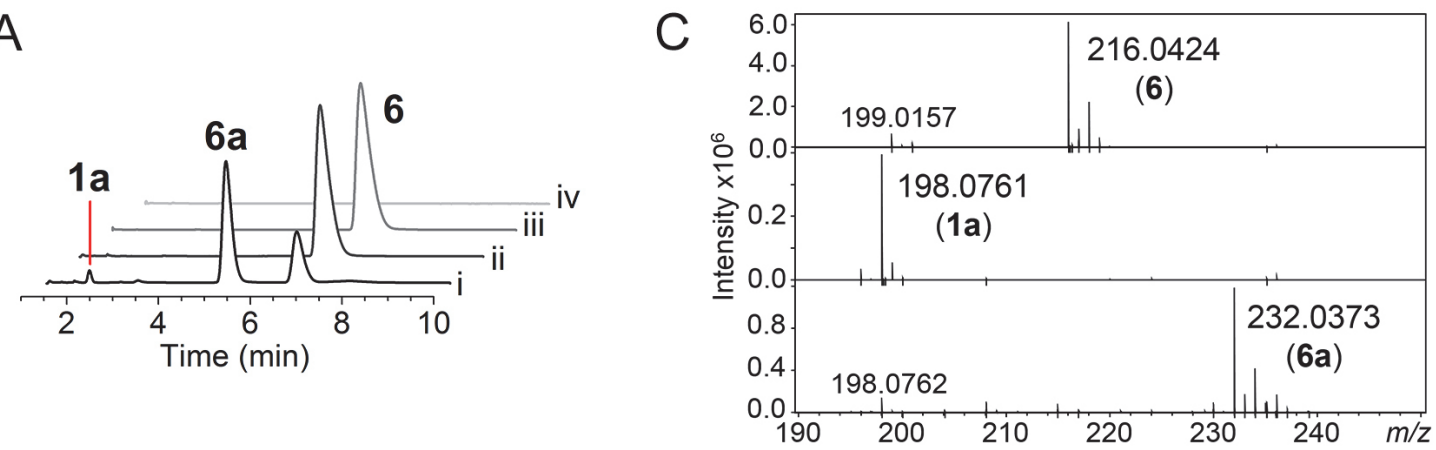

B
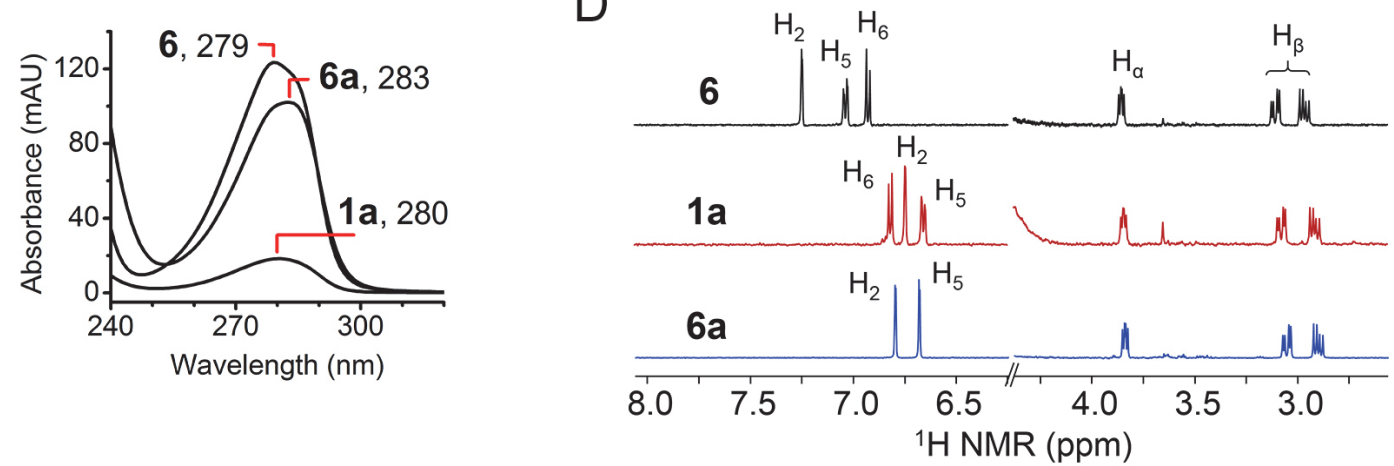

Figure S4. LmbB2 reaction with 3-chloro-L-tyrosine (6) generated and L-3,4dihydroxyphenylalanine (1a) and 3-chloro-5-hydroxyl-L-tyrosine (6a). (A) Two product peaks were detected by HPLC. The enzymatic reaction (i) consisted $100 \mu \mathrm{M}$ enzyme, 3 $\mathrm{mM} 6$ and $3 \mathrm{mM} \mathrm{H}_{2} \mathrm{O}_{2} . \mathrm{H}_{2} \mathrm{O}_{2}$ was titrated to initiate the reaction by adding multiple times and small volume each time to final concentration of $3 \mathrm{mM}$ to avoid heme bleaching. Three controls consisted (ii) enzyme with $\mathbf{6}$, (iii) $\mathbf{6}$ with $\mathrm{H}_{2} \mathrm{O}_{2}$ and (iv) enzyme with $\mathrm{H}_{2} \mathrm{O}_{2}$. (B) Absorbance spectra of $\mathbf{6}$ (blue) and $\mathbf{6 a}$ (black). (C) High-resolution mass spectra of $\mathbf{6}$, 1a and 6a. (D) ${ }^{1} \mathrm{H}$ NMR analysis 6, 1a and 6a, hydrogen atoms are labeled according to the numbering of carbon. 
A

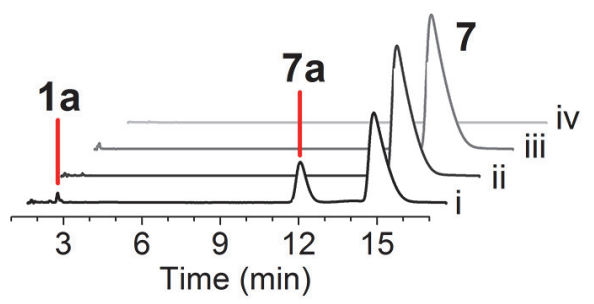

B

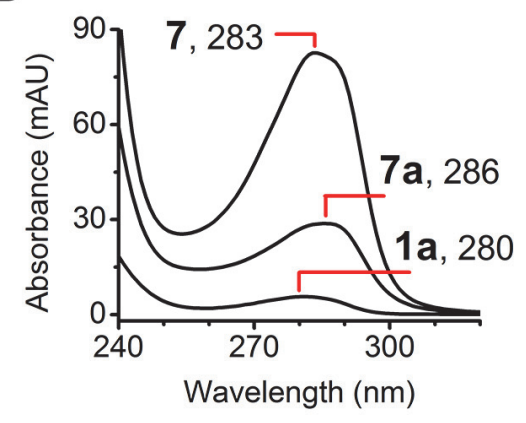

D
C
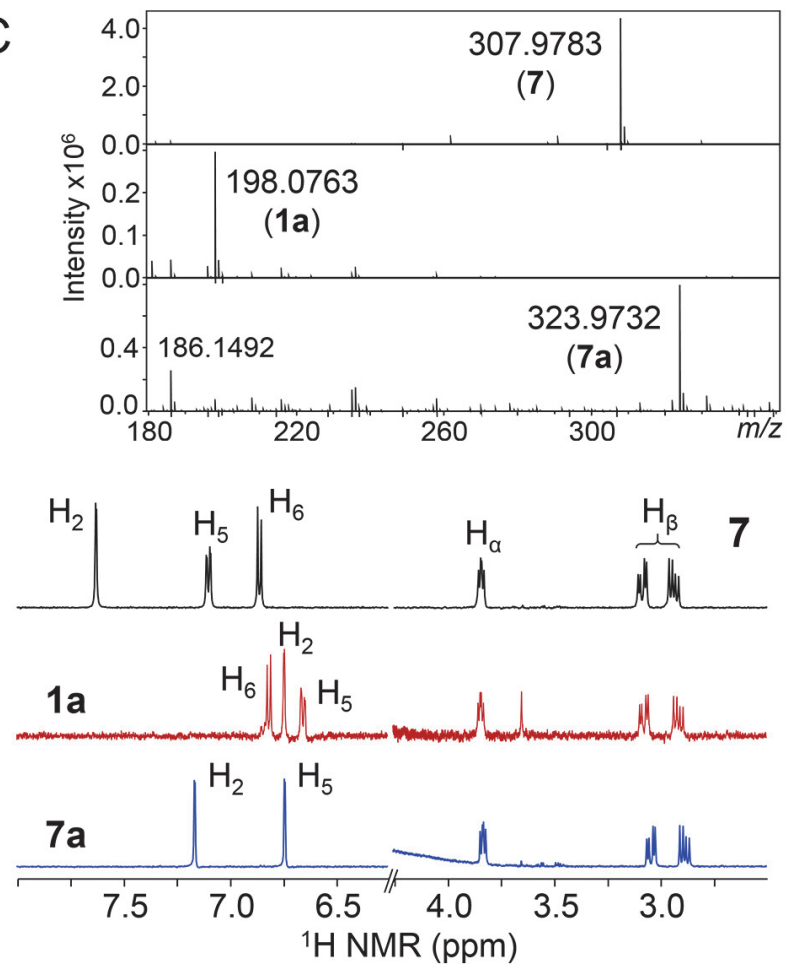

Figure S5. LmbB2 reaction with 3-iodo-L-tyrosine (7) generated and L-3,4dihydroxyphenylalanine (1a) and 3-iodo-5-hydroxyl-L-tyrosine (7a). (A) Two product peaks were detected by HPLC. The enzymatic reaction (i) consisted $100 \mu \mathrm{M}$ enzyme, 3 $\mathrm{mM} 7$ and $3 \mathrm{mM} \mathrm{H}_{2} \mathrm{O}_{2} . \mathrm{H}_{2} \mathrm{O}_{2}$ was titrated to initiate the reaction by adding multiple times and small volume each time to final concentration of $3 \mathrm{mM}$ to avoid heme bleaching. Three controls consisted (ii) enzyme with $\mathbf{6}$, (iii) 6 with $\mathrm{H}_{2} \mathrm{O}_{2}$ and (iv) enzyme with $\mathrm{H}_{2} \mathrm{O}_{2}$. (B) Absorbance spectra of $\mathbf{6}$ (blue) and $\mathbf{6 a}$ (black). (C) High-resolution mass spectra of 7 , 1a and 7a. (D) ${ }^{1} \mathrm{H}$ NMR analysis 7, 1a and 7a, hydrogen atoms are labeled according to the numbering of carbon. 


\section{Kinetic modelling of organic substrates competing with catalase-like activity of LmbB2}

Kinetic modelling of the catalase-like activity of LmbB2 competing with increasing organic substrate (L-tyrosine, $\mathbf{1}$ or 3-fluoro-L-tyrosine, 5) as described in Figure 5C can be approached with a minimal mechanism as shown in Scheme S1. In this model, E

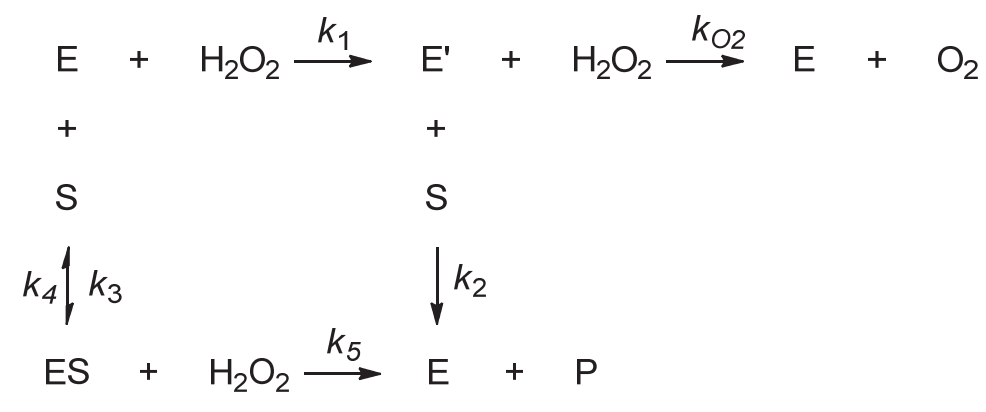

Scheme S1. Minimal competitive model for tyrosine competing with the catalase activity of LmbB2.

represents unbound enzyme, $\mathrm{S}$ is the organic substrate, ES is enzyme bound with the organic substrate, $E^{\prime}$ is the oxidized Compound I-like state of the enzyme, and $\mathrm{P}$ is the hydroxylated product, L-3,4-dihydroxyphenylalanine (DOPA, 1a). Using the Michaelis \& Menten framework for deriving steady-state enzyme kinetics, an expression for the rate of $\mathrm{O}_{2}$ production as a function of $\mathrm{S}$ can be determined. The rate of $\mathrm{O}_{2}$ production is given by eq. 1

$$
\frac{d\left[\mathrm{O}_{2}\right]}{d t}=k_{\mathrm{O}_{2}} \cdot\left[E^{\prime}\right] \cdot\left[\mathrm{H}_{2} \mathrm{O}_{2}\right](1)
$$

As the rate of $\mathrm{O}_{2}$ production is measureable, and hydrogen peroxide is known, an expression for the concentration of E' must be derived. The differential equation describing the change in concentration of $E^{\prime}$ is given in eq. 2 .

$$
\frac{d\left[E^{\prime}\right]}{d t}=k_{1} \cdot[E] \cdot\left[H_{2} O_{2}\right]-\left(k_{2} \cdot\left[E^{\prime}\right] \cdot[S]+k_{O_{2}} \cdot\left[E^{\prime}\right] \cdot\left[H_{2} O_{2}\right]\right)(2)
$$

Invoking the steady state assumption, mass balance of the enzyme states where $\mathrm{E}_{\mathrm{T}}$ is the total enzyme concentration, and collecting like terms gives [E'] as eq. 3 .

$$
\left[E^{\prime}\right]=\frac{\left[E_{T}\right]-[E S]}{\left(\frac{k_{2} \cdot[S]}{k_{1} \cdot\left[H_{2} O_{2}\right]}+\frac{k_{O_{2}}}{k_{1}}+1\right)}
$$

In a similar fashion, an expression for the concentraion of ES can be obtained, eq. 4.

$$
\frac{d[E S]}{d t}=k_{3} \cdot[E] \cdot[S]-\left(k_{4} \cdot[E S]+k_{5} \cdot[E S] \cdot\left[\mathrm{H}_{2} \mathrm{O}_{2}\right]\right)
$$




$$
[E S]=\frac{\left[E_{T}\right]-\left[E^{\prime}\right]}{\left(\frac{k_{4}+k_{5} \cdot\left[\mathrm{H}_{2} \mathrm{O}_{2}\right]}{k_{3} \cdot[S]}+1\right)}
$$

Substition of ES (eq. 4) into the expression for E' (eq. 3) and subsequently into the initial rate expression for $\mathrm{O}_{2}$ production (eq. 1) gives the steady-state equation for the initial rate of the production of $\mathrm{O}_{2}$ by $\mathrm{LmbB} 2$ catalase-like activity in competition with the hydroxylation of an organic substrate, eq. 5 .

$$
\begin{gathered}
V_{0 O_{2}}=k_{O_{2}} \cdot\left[H_{2} O_{2}\right] \cdot\left[E_{T}\right] \cdot \frac{1-\frac{1}{D 1}}{\left(\frac{k_{2} \cdot[S]}{k_{1} \cdot\left[H_{2} O_{2}\right]}+\frac{k_{O_{2}}}{k_{1}}+1-\frac{1}{D 1}\right)} \\
D 1=\left(\frac{k_{4}+k_{5} \cdot\left[H_{2} O_{2}\right]}{k_{3} \cdot[S]}+1\right)
\end{gathered}
$$

The trend of the data obtained from competing LmbB2 catalase-like activity with its native substrate, $\mathbf{1}$, is well captured by eq. 5 , however data obtained using the alternate substrate, $\mathbf{5}$, does not aproach zero at high substrate concentrations and is not well described by above $100 \mu \mathrm{M}$, Figure $\mathbf{S 6}$.

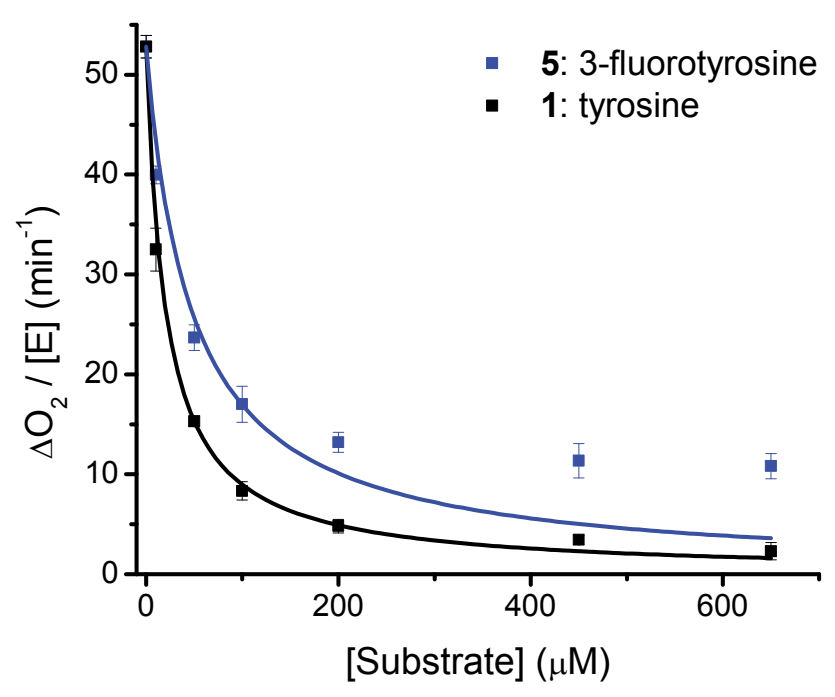

Figure S6. Catalase competition assays as fit by Scheme S1.

If a portion of $\mathbf{5}$ reacts with LmbB2 and hydrogen peroxide as described in Figure 8 to generate DOPA and oxidized LmbB2, then another equivalent of hydrogen peroxide would be required to return LmbB2 to its resting state for the next round of reactions. As such, the competition mechanism of $\mathbf{5}$ should be distinct from $\mathbf{1}$, as it requires that the enzyme may be left in an oxidized state after reaction, Scheme S2. 
Similar as was done above, Scheme $\mathbf{S 2}$ can be used to generate an expression for the rate of $\mathrm{O}_{2}$ production as a function of a substrate which can react normally $\left(k_{5}\right)$ to produce $\mathrm{P} 1$ or produce $\mathrm{P} 2$ (DOPA in the case of fluorotyrosine) via $k_{6}$ while leaving the enzyme in an oxidized state, E', which then requires hydrogen peroxide to return to the resting state. The differential equation which describes the change in concentration of E' is given by eq. 6 .

$$
\begin{aligned}
\frac{d\left[E^{\prime}\right]}{d t}=k_{1} \cdot[E] & \cdot\left[H_{2} O_{2}\right]+k_{6} \cdot[E S] \cdot\left[H_{2} O_{2}\right] \\
& -\left(k_{2} \cdot\left[E^{\prime}\right] \cdot[S]+k_{O_{2}} \cdot\left[E^{\prime}\right] \cdot\left[H_{2} O_{2}\right]\right)
\end{aligned}
$$

Invoking the steady state assumption, mass balance, and collecting like terms gives [E'] as eq. 7.

$$
\left[E^{\prime}\right]=\frac{k_{1} \cdot\left[E_{T}\right]+[E S] \cdot\left(k_{6}-k_{1}\right)}{\left(\frac{k_{2} \cdot[S]}{\left[H_{2} O_{2}\right]}+k_{O_{2}}+k_{1}\right)}(7)
$$

In a similar fashion, an expression for the concentraion of ES can be obtained, eq. 8 .

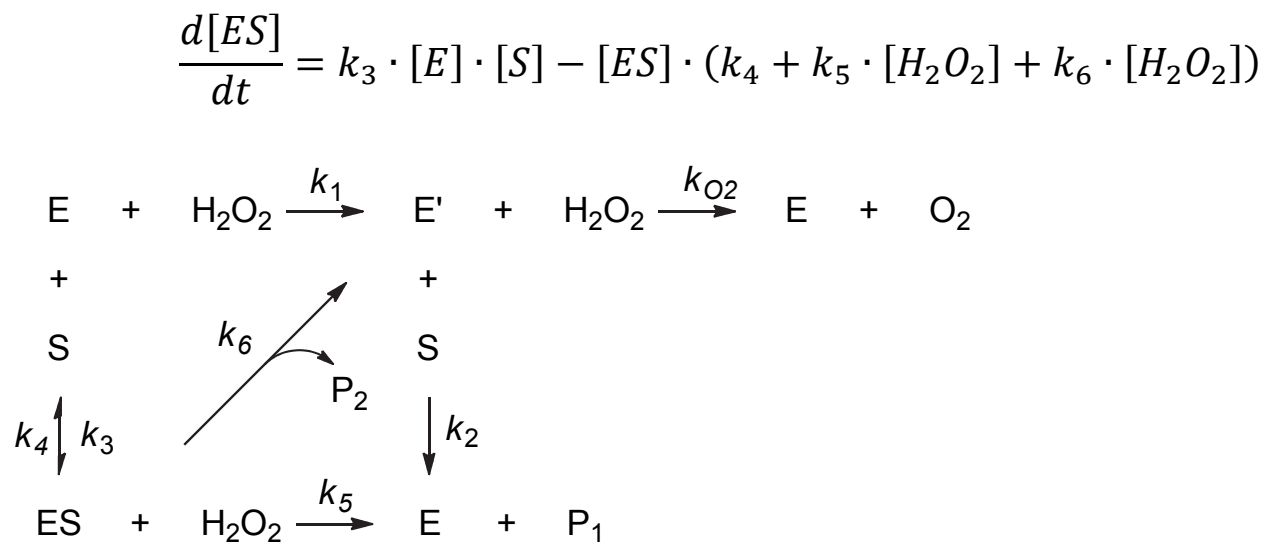

Scheme S2. Minimal competitive model for 3-fluorotyrosine competing with the catalase activity of LmbB2.

$$
[E S]=\frac{\left[E_{T}\right]-\left[E^{\prime}\right]}{\left(\frac{k_{4}+\left(k_{5}+k_{6}\right) \cdot\left[H_{2} O_{2}\right]}{k_{3} \cdot[S]}+1\right)}
$$

Substition of ES (eq. 8) into the expression for E' (eq. 7) and subsequently into the initial rate expression for $\mathrm{O}_{2}$ production (eq. 1) gives the steady-state equation for the initial rate of the production of $\mathrm{O}_{2}$ by LmbB2 catalase activity in competition with the hydroxylation of an organic substrate which can also undergo nucleophilic aromatic substitution, leaving the enzyme in an oxidized state, eq. 9. 


$$
\begin{gathered}
V_{0 O_{2}}=k_{O_{2}} \cdot\left[H_{2} O_{2}\right] \cdot\left[E_{T}\right] \cdot \frac{k_{1}+\frac{k_{6}-k_{1}}{D 2}}{\left(\frac{k_{2} \cdot[S]}{\left[H_{2} O_{2}\right]}+k_{O_{2}}+k_{1}+\frac{k_{6}-k_{1}}{D 2}\right)} \\
D 2=\left(\frac{k_{4}+\left(k_{5}+k_{6}\right) \cdot\left[H_{2} O_{2}\right]}{k_{3} \cdot[S]}+1\right)
\end{gathered}
$$

As shown in Figure S7, inclusion of a pathway by which $\mathbf{5}$ may react with LmbB2 and peroxide leaving the enzyme in an oxidized state which must react with hydrogen peroxide, producing $\mathrm{O}_{2}$, to return to the resting state produces an equation which captures the observed behavior. Fitting the data of catalase activity being inhibited by 5 requires ca. $24 \%$ of the reaction to proceed via the nucleophilic aromatic substitution reaction pathway that produces DOPA and oxidized enzyme. The equation derived from Scheme $\mathbf{S 2}$ can also provide satisfactory description of the tyrosine reaction if the $k_{6}$ parameter is set to zero. In all cases, $k_{\mathrm{O} 2}$ and $k_{1}$ are constrained to the minimal values that produce the correct activity when no organic substrate is present. Similarly, the $k_{5}$ value is set at the $k_{\text {cat }}$ for this activity of $34 \mathrm{~min}^{-1}$. The other microscopic rate constants are not well bounded, so this kinetic analysis should be considered descriptive rather than quantiative. Both eq. 5 and eq 9 were able to fit the experimental data with either $k_{2}$ or $k_{3}$ as a large number with the other near zero; fittings with intermediate values produced sigmodial lineshapes which do not describe the data. However, fitting with a large $k_{2}$ and near zero $k_{3}$ does not make physical sense, as the $K_{\mathrm{d}}$ for substrate binding is known to be in the micromolar range, therefore this analysis demonstrates that organic substrates are not kinetically competent to compete with hydrogen peroxide for a preformed oxidized enzyme.

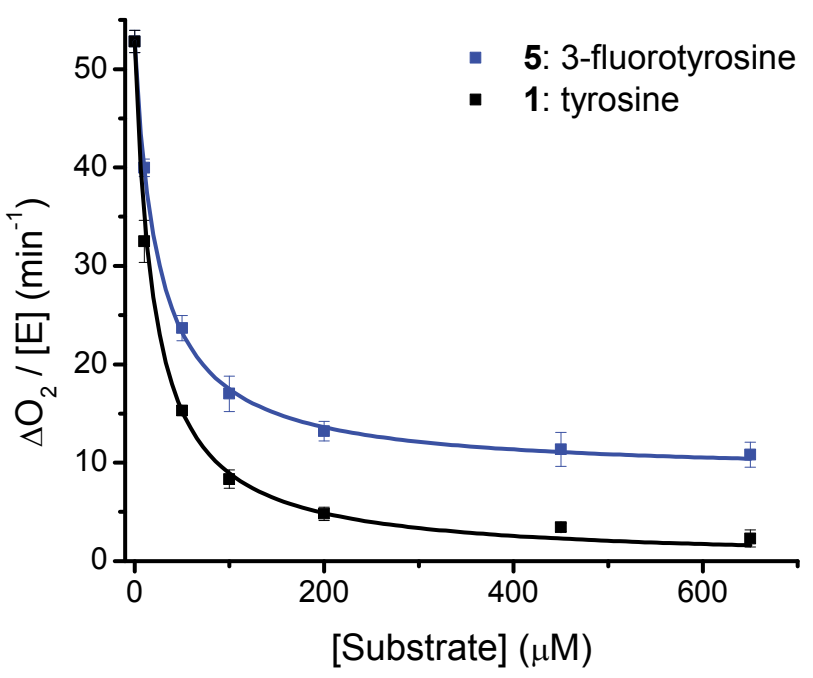

Figure S7. Catalase competition assays as fit by Scheme S2. 

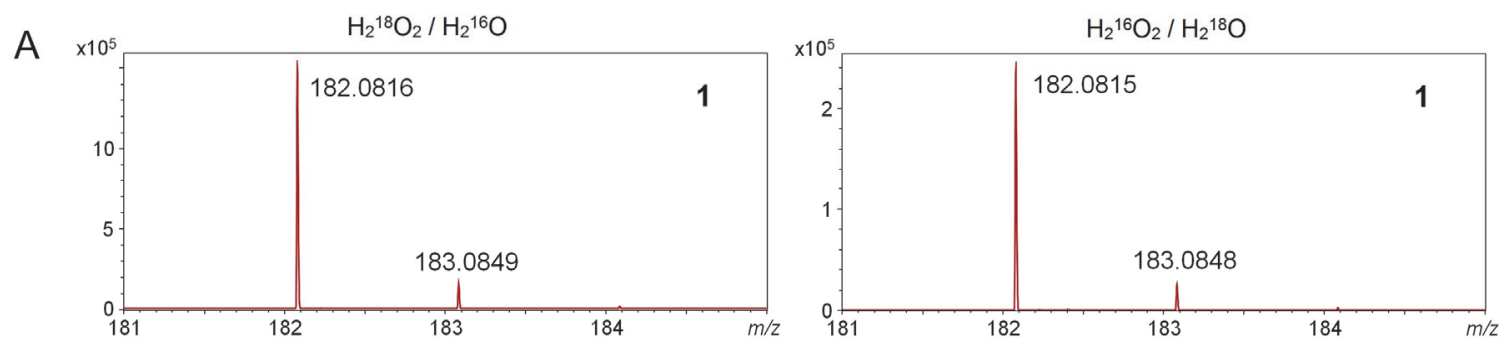

B
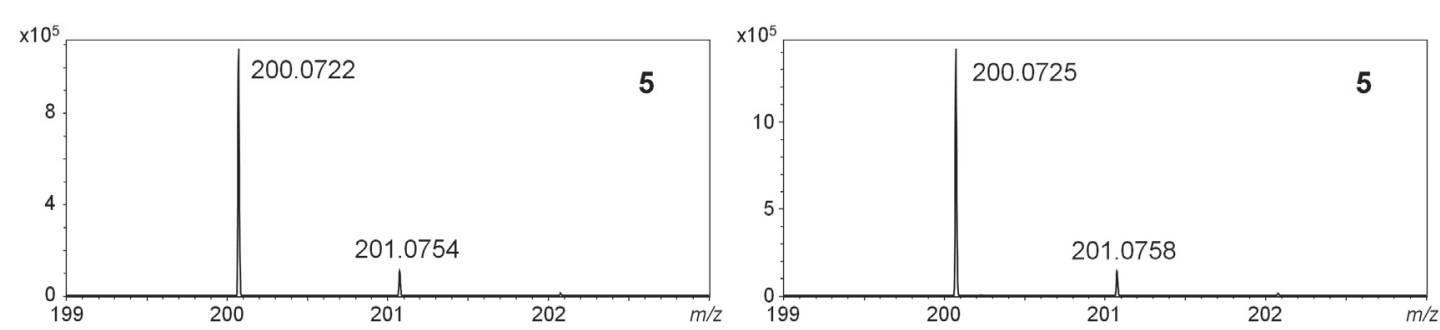

Figure S8. $\mathrm{MS}$ analyses on unreacted substrates with ${ }^{18} \mathrm{O}$ labeled $\mathrm{H}_{2} \mathrm{O}$ and $\mathrm{H}_{2} \mathrm{O}_{2}$. Ltyrosine (1) (A) and 3-fluoro-L-tyrosine (5) (B)were used as substrates. Reactions were carried out with isotope labeled water (left) or hydrogen peroxide (right). 

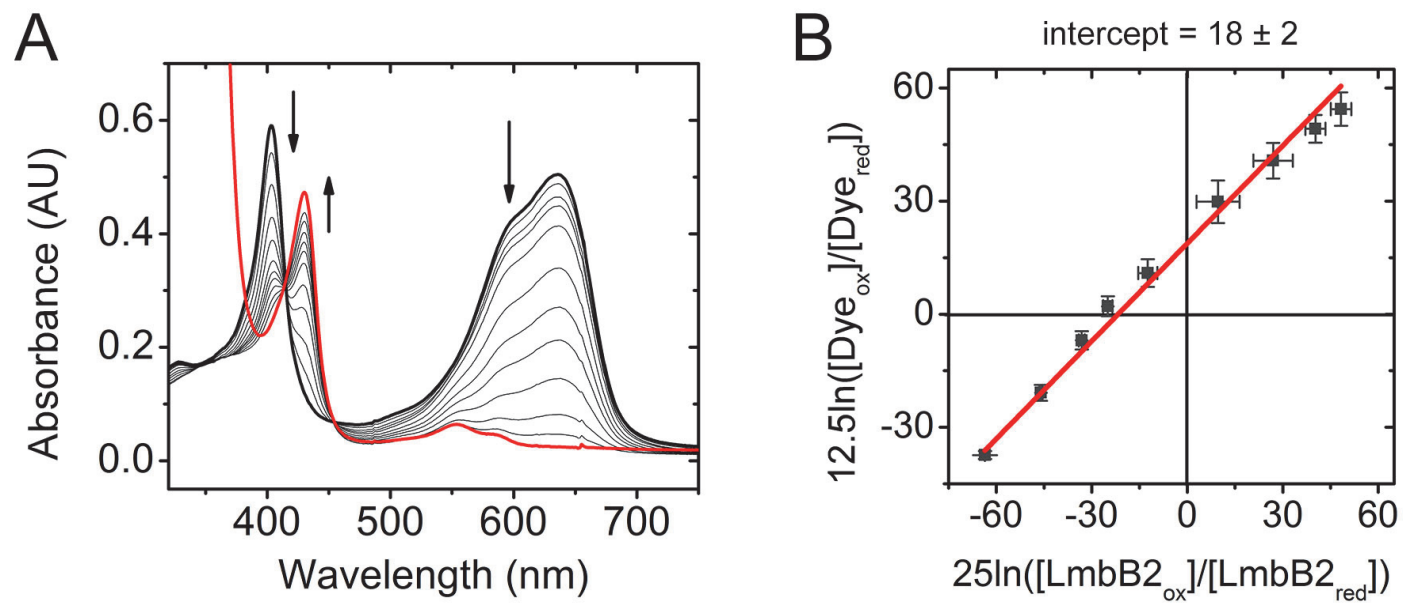

Figure S9. LmbB2 redox potential measurement. (A) Representative spectra for the reduction of LmbB2 and Nile Blue. (B) Corresponding Nernst plot with 3 repeated trials. Linear fitting (red line) yielded a y-intercept of $18 \pm 2$. 
NMR data for tyrosine analogs and their products

Peak assignments were based on coupling constant and chemical shift.

1a, ${ }^{1} \mathrm{H}$ NMR $\left(500 \mathrm{MHz}, \mathrm{D}_{2} \mathrm{O}\right) \delta 6.87(\mathrm{~d}, J=8.1 \mathrm{~Hz}, 1 \mathrm{H}), 6.80(\mathrm{~d}, J=1.9 \mathrm{~Hz}, 1 \mathrm{H}), 6.71$

$(\mathrm{dd}, J=8.3,1.8 \mathrm{~Hz}, 1 \mathrm{H}), 3.90(\mathrm{dd}, J=7.9,5.0 \mathrm{~Hz}, 1 \mathrm{H}), 3.13(\mathrm{dd}, J=14.7,5.1 \mathrm{~Hz}, 1 \mathrm{H})$, $2.97(\mathrm{dd}, J=14.7,7.9 \mathrm{~Hz}, 1 \mathrm{H})$.

4, ${ }^{1} \mathrm{H}$ NMR $\left(500 \mathrm{MHz}, \mathrm{D}_{2} \mathrm{O}\right) \delta 7.97(\mathrm{~d}, J=2.2 \mathrm{~Hz}, 1 \mathrm{H}), 7.50(\mathrm{dd}, J=8.6,2.3 \mathrm{~Hz}, 1 \mathrm{H})$, $7.11(\mathrm{~d}, J=8.6 \mathrm{~Hz}, 1 \mathrm{H}), 3.91(\mathrm{dd}, J=7.2,5.8 \mathrm{~Hz}, 1 \mathrm{H}), 3.18(\mathrm{dd}, J=14.7,5.6 \mathrm{~Hz}, 1 \mathrm{H})$, $3.09(\mathrm{dd}, J=14.7,7.4 \mathrm{~Hz}, 1 \mathrm{H})$.

4a, ${ }^{1} \mathrm{H}$ NMR (500 MHz, D $\left.2 \mathrm{O}\right) \delta 7.57$ (s, 1H), 7.13 (s, 1H), 3.94 (dd, J=7.4, $\left.5.6 \mathrm{~Hz}, 1 \mathrm{H}\right)$, $3.18(\mathrm{dd}, J=14.8,5.4 \mathrm{~Hz}, 1 \mathrm{H}), 3.06$ (dd, $J=14.7,7.6 \mathrm{~Hz}, 1 \mathrm{H})$.

5, ${ }^{1} \mathrm{H}$ NMR $\left(500 \mathrm{MHz}, \mathrm{D}_{2} \mathrm{O}\right) \delta 7.00(\mathrm{~d}, J=12.2 \mathrm{~Hz}, 1 \mathrm{H}), 6.96-6.86(\mathrm{~m}, 2 \mathrm{H}), 3.86(\mathrm{dd}, J$ $=7.9,5.2 \mathrm{~Hz}, 1 \mathrm{H}), 3.11(\mathrm{dd}, J=14.7,5.2 \mathrm{~Hz}, 1 \mathrm{H}), 2.97(\mathrm{dd}, J=14.7,7.8 \mathrm{~Hz}, 1 \mathrm{H}) .{ }^{19} \mathrm{~F}$ NMR (471 MHz, $\left.\mathrm{D}_{2} \mathrm{O}\right) \delta-137.68(\mathrm{dd}, J=12.5,9.2 \mathrm{~Hz})$.

5a, ${ }^{1} \mathrm{H}$ NMR $\left(500 \mathrm{MHz}, \mathrm{D}_{2} \mathrm{O}\right) \delta 6.59(\mathrm{dd}, J=11.0,2.1 \mathrm{~Hz}, 1 \mathrm{H}), 6.56(\mathrm{~d}, J=2.0 \mathrm{~Hz}, 1 \mathrm{H})$, $3.85(\mathrm{dd}, J=7.9,5.1 \mathrm{~Hz}, 1 \mathrm{H}), 3.06(\mathrm{dd}, J=14.7,5.0 \mathrm{~Hz}, 1 \mathrm{H}), 2.91(\mathrm{dd}, J=14.7,7.9 \mathrm{~Hz}$, 1H). ${ }^{19} \mathrm{~F} \mathrm{NMR}\left(471 \mathrm{MHz}, \mathrm{D}_{2} \mathrm{O}\right) \delta-137.58(\mathrm{~d}, J=10.0 \mathrm{~Hz})$.

6, ${ }^{1} \mathrm{H}$ NMR $\left(500 \mathrm{MHz}, \mathrm{D}_{2} \mathrm{O}\right) \delta 7.25(\mathrm{~d}, J=1.8 \mathrm{~Hz}, 1 \mathrm{H}), 7.03(\mathrm{dd}, J=8.4,1.9 \mathrm{~Hz}, 1 \mathrm{H})$, $6.92(\mathrm{~d}, J=8.4 \mathrm{~Hz}, 1 \mathrm{H}), 3.85(\mathrm{dd}, J=7.8,5.3 \mathrm{~Hz}, 1 \mathrm{H}), 3.11$ (dd, $J=14.7,5.3 \mathrm{~Hz}, 1 \mathrm{H})$, $2.96(\mathrm{dd}, J=14.7,7.8 \mathrm{~Hz}, 1 \mathrm{H})$.

6a, ${ }^{1} \mathrm{H}$ NMR $\left(500 \mathrm{MHz}, \mathrm{D}_{2} \mathrm{O}\right) \delta 6.80(\mathrm{~d}, J=1.9 \mathrm{~Hz}, 1 \mathrm{H}), 6.68(\mathrm{~d}, J=1.9 \mathrm{~Hz}, 1 \mathrm{H}), 3.84$ $(\mathrm{dd}, J=7.9,5.1 \mathrm{~Hz}, 1 \mathrm{H}), 3.05(\mathrm{dd}, J=14.7,5.1 \mathrm{~Hz}, 1 \mathrm{H}), 2.90(\mathrm{dd}, J=14.7,7.9 \mathrm{~Hz}, 1 \mathrm{H})$. 7, ${ }^{1} \mathrm{H}$ NMR $\left(500 \mathrm{MHz}, \mathrm{D}_{2} \mathrm{O}\right) \delta 7.63(\mathrm{~d}, J=2.0 \mathrm{~Hz}, 1 \mathrm{H}), 7.10(\mathrm{dd}, J=8.3,2.0 \mathrm{~Hz}, 1 \mathrm{H})$, $6.86(\mathrm{~d}, J=8.2 \mathrm{~Hz}, 1 \mathrm{H}), 3.90-3.76(\mathrm{dd}, J=7.8,5.1 \mathrm{~Hz}, 1 \mathrm{H}), 3.09(\mathrm{dd}, J=14.7,5.2 \mathrm{~Hz}$, $1 \mathrm{H}), 2.94(\mathrm{dd}, J=14.8,7.8 \mathrm{~Hz}, 1 \mathrm{H})$.

7a, ${ }^{1} \mathrm{H}$ NMR $\left(500 \mathrm{MHz}, \mathrm{D}_{2} \mathrm{O}\right) \delta 7.16(\mathrm{~d}, J=1.8 \mathrm{~Hz}, 1 \mathrm{H}), 6.74(\mathrm{~d}, J=1.8 \mathrm{~Hz}, 1 \mathrm{H}), 3.83$ $(\mathrm{dd}, J=7.8,5.1 \mathrm{~Hz}, 1 \mathrm{H}), 3.04(\mathrm{dd}, J=14.7,5.1 \mathrm{~Hz}, 1 \mathrm{H}), 2.89$ (dd, $J=14.7,7.9 \mathrm{~Hz}, 1 \mathrm{H})$. 